\title{
Influence of Team Management Practices on Performance of Community-Based Projects in Embu County, Kenya
}

\author{
Njue, Nicasio Gicovi, PhD Candidate (Project Planning and \\ Management) \\ Dr. Chandi, John Rugendo, Lecturer
}

Department of Open Learning, School of Open and Distance Learning, University of Nairobi, Kenya

Doi:10.19044/esj.2019.v15n10p293 URL:http://dx.doi.org/10.19044/esj.2019.v15n10p293

\begin{abstract}
The purpose of this study was to examine the influence of team management practices (team formation, team motivation, team communication and team dispute resolution) on the performance of community-based projects in Embu, Kenya. Appropriate research hypothesis was derived from the substantive objective. Descriptive-correlational survey design was used to implement the research inquiry. The target population was 34 community-based projects in being implemented in Embu County. A sample of 32 projects was arrived at using Krejcie and Morgan table of sample determination. Proportionate stratified random sampling was used to select 32 project team leaders. Appropriate data was garnered using structured questionnaires. Data were analyzed using descriptive and inferential statistics. The results suggest that at $\mathrm{F}(1,156)=4.934, \mathrm{P}=0.000<0.05$ implying that at $95 \%$ the relationship was statistically significant. The correlation coefficient $(\mathrm{R}=0.653)$ showed that there exists strong positive correlation between team management practices and performance community-based projects. The coefficient of determination $\left(\mathrm{R}^{2}=0.426\right)$ implied that team management practices explained $42.6 \%$ of performance of community-based projects. The findings have immense contribution to both knowledge and practice in the areas of team management practices and performance of community-based projects. Follow up studies should focus on testing similar variables across different project set-ups while triangulating different methodologies in order to derive more generalizable results.
\end{abstract}

Keywords: Team formation, team motivation, team communication, dispute resolution, performance of community-based projects. 


\section{INTRODUCTION}

Proponents of community-based approaches to development aver that community led projects are a promising means of shifting communities from dependency to empowerment and sustainable development (Githua and Wanyoike, 2015). In the recent past, the way community-based projects are coordinated and organized towards sustainable deliverables is gaining research attention. This is due to increased ability of community-based projects to employ social resources, community resources, structures and networks for informed decision making on community matters whose interests and areas of action represent that of the community (Torri, 2009). In addition, community-based approaches are the most effective means through which locals become actively involved in decision making, designing, resource allocation, management and thus exercise control over development initiatives for productive, responsive and sustainable impacts which include poverty alleviation and socioeconomic development (Peredo and Chrisman, 2006). In Thailand for example, community value-addition projects have facilitated backward and forward linkages across sectors thus creating employment to over 1.5 million people (Srikaew and Baron 2009). In Japan and Thailand, value-addition community projects (One Village One Product- OVOP) have provided rapid development of community entrepreneurship (Claymome and Jaiborisudhi, 2011). In Ethiopia, community-based endogenous projects have helped to revitalize local resources through participatory approaches that help in rediscovering and activation of local potentials thus creating employment and income generating opportunities for enhanced livelihoods (Desta, 2012). This is supported by the findings from a study on the impact of community projects in central Kenya by Ohaya, Misigah, and Kinyanjui (2015) that localization of community projects promotes positive image that drives efficiency and effectiveness in driving sustainable change.

Nevertheless, project team management is one of impediments to the success of many community projects (Claymome and Jaiborisudhi, 2011). According to Hofisi and Chizimba (2013), low level of empowerment to the project members is one of the contributing factors to poor performance (Oino, Towett, Kirui, and Luvega, 2015). A study by Mwaura and Ngugi (2014) on the factors affecting performance of community-based organizations projects in Kisii, Kenya supports similar views that poor management of teams and stakeholders is has led to inefficiencies and ineffectiveness of community projects. Whereas appropriate and effective team development approaches increases individual's sense of determination in performing project tasks on project success (Zwikael and Unger-Aviram, 2010), there is limited literature on how this hypothesis applies to community-based projects. While poor management of teams in community projects has been cited to delay project completion (Teller and Kock, 2013), observations in Embu, Kenya suggest 
that a good number of community value-addition projects have delayed in their completion thus postponing the realization of the intended benefits. In addition, there are reports suggesting that delays in completion of the community projects is attributed to team dynamics among the community members who run these projects. This raises the question as to whether team management approaches have any contribution to this constraint. Hence, this study sought to examine the influence of team management practices on the performance of community-based projects in Embu County.

In Embu County there were thirty-four (34) community-based valueaddition projects (Republic of Kenya, 2017). The main endeavor of the projects entails processing locally available resources like banana, sorghum, maize, sunflower, milk, cassava, Irish potatoes, green grams, fruits, sweet potatoes, milk, maize, sorghum etc. into finished products. The finished products are then sold at a higher value for income generation and employment creation. The community-based projects are managed by community under the leadership of the nominated team leaders who lead and direct other members and also perform managerial functions like planning, organization, coordination and controlling processes in support of other team members.

\section{LITERATURE REVIEW \\ Project Performance}

Project performance is a measure of the progress and achievements made during the project implementation discourse relative to the planned expectations (Chan and Chan, 2004). According to Shenhar, Levy and Dvir (1997), project performance can be measured by various dimensions like customer satisfaction, efficiency in budget and schedules, business success and future potential. Also, project performance can be measured based on the extent of meeting design goals and benefits accrued (Sadeh and Shenhar, 2000). From a broader perspective, Chan and Chan (2004) argues that project performance can be measured by eight dimensions namely: cost, quality, time, environmental performance, user expectation/satisfaction, commercial/profitable value, health and safety, participants' satisfaction. This is supported by Project Management Institute (PMI, 2013) who proposes evaluation of project success based on the dimensions of cost, time, quality and stakeholder satisfaction. Empirically, there lacks consented criteria for assessing project performance. However, due to the dynamic nature of community members who constitute the project team, performance of community projects was measured by the level of resource efficiency, task completion, completeness of outputs and team satisfaction. 


\section{Team Management Practices}

Practices are the activities done to depict a set of principles like collecting customer information, improving work processes and managing employees (Mose and Kibera, 2015). However, there lacks empirical consent on the best practices towards effective team management. In this view, Ramabadron, Dean and Evans (1997) aver that team management practices will continue to differ from one project to another depending on the project context. In his conceptualization of what team management may entail, Tuckman (1965) theorized team development in five main development stages namely: forming, storming, norming, performing and adjourning. In their studies on team performance, Tsiga, Emes and Smith (2016) found that team management aspects like team selection, team commitment, adequate team capability, communication are part of critical success factors to projects. In support, Jayarathn and Weerakkody (2016), team management practices enhance team productivity and performance. IT Implies that the contribution of team productivity and performance to the overall project performance cannot be alienated in the context of community projects. This study conceptualized team management practices as the works done to team members to achieve higher and satisfactorily project performance. These works include: team formation, team motivation, team communication and team dispute resolution.

Formation of teams need not have technical competence but rather comprehensive people management skills (Kara and Kester, 2015). However, quality of team members is much more determining factor of project success over methods, tools and techniques used to run project. This calls for elaborate and competitive selection of team members (Ancona and Caldwell, 1992). Team formation was indicated by the levels of formality in selection, competence criterion, level of commitment and expectations of the team members.

There are numerous practices and approaches to team motivating which includes but not limited to empowerment, rewards, recognition, facilitating support, diversifying tasks, encouragement, fair treatments, involvement (Kara and Kester, 2015). Team motivation reduces absenteeism while increasing satisfaction and desires to accomplish individual tasks hence increased organizational performance (Dobre, 2013). Empowered and motivated team are able to develop commitment and understanding thus they dedicate their interests and efforts aligned and coordinated towards project goals. Motivated workforce is always willing to reinforce efforts and take action towards realization of project goals. However, the main challenge for many organizations is finding the right ways to create and sustain individual motivation (Dobre, 2013). Based on the commune nature of the projects under 
consideration, team motivation was indicated by the levels of empowerment, reinforcement and facilitation.

According to Smidts, Pruyn and van Riel (2001), positive climate and effective team communication is claimed to strengthen teams' sense of identification and loyalty to a project which in turn contributes to the overall project performance and success. In past, the quality of team communication has reliably been measured by the frequency, time spent and the degree of formalization or spontaneity in terms of planning, reporting, and positions statuses in the course of information sharing (Pinto and Pinto, 1990). Studies have established that communication practices that are simple, open, honest, timely, rich in content and rationale of requirements and relevant to individuals and project tasks are easy to comprehend and build trust that is essential for successful decision making and team performance (Thamhain 2004). Therefore, effective team communication need be interactive, understandable and able to drive commitment and action. Hence, team communication was measured by communication frequency, level of communication, level of proximity and level of interactive communication influence project performance.

Finally, disputes are disagreements among team members. A study by Thomas and Schmidt (1976) reveals that managers spends approximately $20 \%$ of time solving disputes. The link between team dispute and team performance is demonstrated by moderate to strong negative correlations between team conflict, team performance, and team member satisfaction. Conflicts will always arise in teams due to factors like limited resources, competing interests, work environment, team diversity in terms of values, culture, believes, and other background and personal differences. Dispute resolution has reliably been measured by aspects of team cohesion namely: clarity of purpose, level of informality, participation, listening, consensus decisions, open communication, clarity of roles and work assignments, shared leadership, external relations, style diversity and self-assessment (Wu and Chen, 2014). In this study, team dispute resolution practices were indicated by clarity of purpose, participation, freedom, team cohesion

\section{Summary of Research Gaps}

While using a correlational survey design to study the implementation of team member selection and the level of actions taken to manage the effects of complexity of interconnections, Antoniadis (2012) used questionnaire and interview guide to gather data from 180 workers and 17 randomly selected project management professionals, and descriptive statistics revealed the criteria for selecting project team members decreased in the following order: availability, capability, technical skills, management skills, leadership skills 
and experience. However, the study findings could not be generalized across community-based projects settings due to lack of external validity

A correlational survey by Jayarathna and Weerakkody (2016) to examine the impact of decision making and reward management on job performance using self-administered questionnaire and 311 randomly selected employees found that decision making and reward management on job performance had significant and partial mediation effects on job satisfaction and performance. Nevertheless, the reward effects on job satisfaction were tested in a functional organization thus limiting their generalization to projects which are uniquely executed in the context of team diversity. Hence this study sought to examine the influence of team management practices on the performance of community-based value-addition project in Embu County. The variables of interest were team formation, team motivation, team communication and team dispute resolution.

Chiocchio (2007) conducted a cross-sectional survey to investigate how team members communicate on issues of task assignment and coordination over time. While using questionnaires to gather data from a convenient sample of 134 teams, inferential analysis found that highperforming teams communicated and exchanged more messages for informed decision making. However, the simulation study used non-random sample thus limiting the validity of the findings real life experience thus limiting validity and generalization.

Shaw, Zhu, Duffy et al (2011) conducted related survey to examine the relationships of task conflict, relationship conflict, and team effectiveness in Taiwan and Indonesia. While using structured questionnaires to collect data from 287 randomly selected work teams, inferential statistics revealed that the relationship conflict was found to moderate the task conflict-team performance relationship. However, study findings could not be generalized to all types of projects due to limitations in methodology.

\section{PROBLEM STATEMENT}

Worldwide, community-based approach is one of the fastest growing vehicles towards realization of equitable community development, flattening the administrative bureaucracies and allowing full community empowerment and participation (Mwaura and Ngugi, 2014). As a result, community-based projects have bolstered local capacity in infrastructure and services, strengthening local expertise in decision making, promote economic independency, facilitate long term more democratic, decentralized, participatory governance (Githua and Wanyoike, 2015). By this recognition, the Government of Kenya through the Ministry of Public Service, Youth and Gender Affairs disbursed over KSh. 68,643, 623 to support over 763 community groups projects comprising of 198 youth groups, 551 women 
groups and 23 groups of peoples with disability in Embu County (Republic of Kenya, 2018). However, observations suggest that as community-based projects continue to proliferate in Embu County, majority of the projects have either dragged for longer time prior to their completion or failed. Residents claim that delays in the completion of the community projects in Embu relate to team dynamics among the community members who largely constitute the project teams.

Previous empirical studies have attempted to link poor team management to low productivity and reduced performance (Jayarathn and Weerakkody, 2016; Lindsjorn, Sjoberg, Dingsoyr, Bergersen and Dybaa; 2016; Schnetler, Steyn and van Staden, 2015; Githua and Wanyoike, 2015). Also, this is demonstrated by Thomas, Jacques, Adams and KihnemanWooten (2008) that organizations with high orientation towards effective team development derives full project ownership and have got strong chances of effective project planning and control of project performance. A study on the factors of project performance by McManus and Wood-Harper (2007) suggests that about $65 \%$ of causal factors to poor performance and failure of projects is caused by among other factors poor team leadership. However, a study conducted by Hyvari (2006) to examine project performance indicated that certain team management aspects decreased their influence on project performance in the following order: competence (23\%), commitment (22\%), and communication (18\%), trouble shooting (8\%), monitoring and feedback (7\%). In support, Lindsjorn, Sjoberg, Dingsoyr, Bergersen and Dybaa (2016) aver that teamwork quality, team learning and work satisfaction have strong positive contribution to project success.

Nevertheless, the existing empirical findings cannot just be generalized to all projects and especially community projects whose team membership is largely the diverse community members. Equally, management of community projects requires more participatory approaches to team management due to their commune nature. Community projects in Embu County are examples of community projects whose contribution of team management practices to the project performance is yet to be empirically established. Therefore, this study sought to examine the contribution of team management practices on the performance of community-based projects in Embu County. Specific areas of interest that will form part of recommendations to practitioners in community development will be team formation, team motivation, team communication and team dispute resolution.

The conceptual framework for the influence of team management practices on the performance of community-based projects is presented in Figure 1 as illustrated below. 


\section{Figure 1 Conceptual Framework}

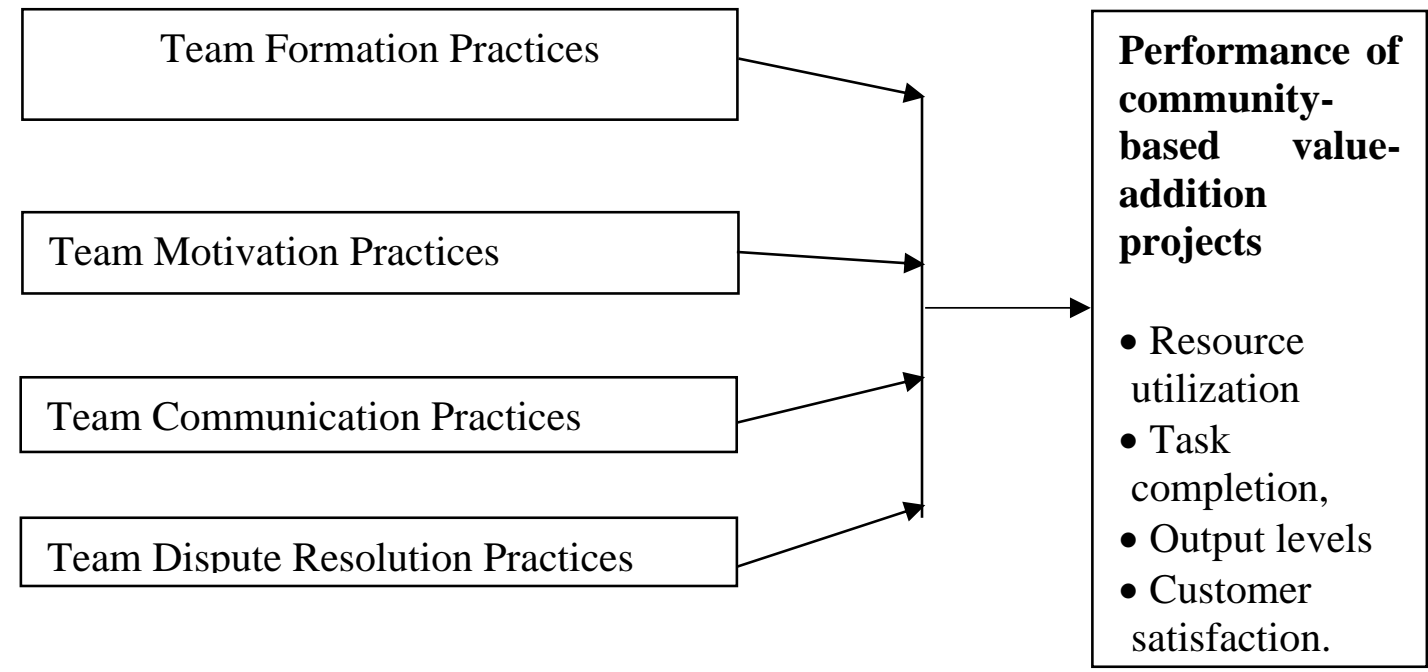

Figure 1: Conceptualization of the relationship between team management practices and performance of community-based projects.

\section{Research Objectives}

The general objective of this study was to examine the influence of team management practices on performance of community-based projects in Embu County. The specific objectives were:

1. To investigate the extent to which team formation practices influence performance of community-based projects in Embu County.

2. To establish the extent to which team motivation practices influence performance of community-based projects in Embu County.

3. To investigate the extent to which team communication practices influence performance of community-based projects in Embu County.

4. To establish the extent to which team dispute resolution practices influence performance of community-based projects in Embu County.

\section{Research Hypothesis}

The study aimed at testing the following hypothesis:

$\mathbf{H}_{\mathbf{0}}$ : There is no significant influence of team management practices on the performance of community-based projects

$\mathbf{H}_{\mathrm{A}}$ : There is significant influence of team management practices on the performance of community-based projects 


\section{Theoretical Framework}

This study was founded upon two theoretical frameworks namely; theory of team development and theory of human motivation. While theory of team development was used to explain how team management practices address the challenges in team development at each level, theory of human motivation supported how satisfied project team members commit and dedicate their efforts for project to perform and succeed. In theory of team development, there are four main development stages namely forming, norming, storming, and performing (Tuckman, 1965). Project team leader must create processes and procedures to deal with the relationship and task challenges so as to increase chances of teams' acceptance to responsibilities. Motivation theories emerged in the early 1990s following studies to understand the human behavior organizations. Literature suggest that external motivation tools rewards, praises and recognition etc., boost intrinsic motivation essential for boosting individual and team morale in coordinating efforts for continuous learning, improvement and project performance (Schnetler, Steyn and Van Staden, 2015). This calls for project managers to understand individuality, needs and motivators for connecting team members with management so as to foster healthy environments for acceptance of assignments, responsibilities and fulfillment of project objectives.

\section{METHODOLOGY}

\section{Research Design}

A descriptive-correlational survey design was used to facilitate description of the relationships between team management practices and project performance (Best and Kahn, 2009). Descriptive survey design was selected due to its ability to describe the practices, processes and structures of a phenomenon under study while trying to determine the extent of relationships among variables (Best and Kahn, 2009). Through descriptive survey approach, questionnaires were used to gather data from the community project leaders at a given time so as to describe and estimate the prevalence of phenomenon while providing a snapshot of the characteristics of interest.

\section{Target Population}

The target population was all 34 registered community-based valueaddition projects in Embu County. These projects were distributed in the four (4) sub-counties of Embu County namely: Runyenjes, Manyatta, Mbeere South and Mbeere North. Due to the regular patterns that characterize community development projects, it was expected that the findings from the study are generalizable across all the community development projects in Embu County. 


\section{Sample Size and Sampling Procedures}

This study was guided by Krejcie and Morgan (1970) table of sample determination to randomly select 32 project team leaders from the possible 34 team leaders of the 34-existing community-based value-addition projects as provided by the Embu County Government. Proportionate stratified random sampling technique was used to independently and randomly select 32 respondents from the list of community-based valued addition teams. The 32 cases were above the minimum requirements of 30 cases for correlation analysis (Best and Kahn, 2009).

\section{Data Collection Instruments}

This study used structured questionnaires to collect quantitative data from the 32 respondents. A questionnaire is list of questions prepared for respondents' answer (Best and Kahn, 2009). While questionnaires are objective, easy to administer and can collect data from large group of respondents in a short time at minimal cost, they may be difficult for respondents to comprehend.

\section{Validity and reliability}

This study enhanced the instrument validity through matching research questions with question in the questions and seeking expert opinion from supervisor. Using the recommendations of George and Mallery (2003), the reliability of the Likert-scale questionnaires was determined using Cronbach's Coefficient Alpha method at $\alpha=0.80$.

\section{Data Analysis Methods}

The study used both descriptive statistics such as percentages, standard deviation, arithmetic mean and inferential statistics like correlational, regression and testing of hypothesis to analyze the quantitative data. Using Ftest, Pearson`s Correlation Coefficient ( $r$ ) and Regression analysis (coefficient of determination- $\mathrm{R}^{2}$ ) were used in testing hypothesis using and predicting the model respectively.

\section{Ethical Consideration}

The researcher fulfilled all legal, moral and social obligations before, during and after the study so as to safeguard the rights of the research subjects and other parties interested or affected by the study. Professional and academic requirements or guidelines were adhered to throughout the study. Approvals and permit were sought from the relevant authorities including the University and the National Commission for Science, Technology and Innovation (NACOSTI). In addition, respondents were voluntarily allowed to participate in the research process and confidentially was held without biasness. A 
consent declaration form was signed by the research participant to safeguard confidentiality, disclosure of identity, Privacy, voluntarily nature, consent, deception, anonymity, embarrassment etc. as discussed in the next section.

\section{RESULTS}

\section{Questionnaire Return Rate}

The response rate was $88.2 \%$ (30 out of 32) which is far above the minimum recommendation of $80 \%$ for analysis and conclusion of a survey findings (Fincham, 2008).

Objective One: Correlation of Team Formation and Performance of Community-based Projects

Using Pearson's Correlation Method, the relationship between team formation and performance of community-based projects was computed and the correlational results are presented in Table 4.1

Table 4.1. Correlation of Team Formation and Performance of Community-based Projects

\begin{tabular}{|c|c|c|c|}
\hline & & Performance & Team formation \\
\hline \multirow{3}{*}{$\begin{array}{l}\text { Performance of } \\
\text { community-based } \\
\text { projects }\end{array}$} & Pearson & 1 & .378 \\
\hline & Sig. (2-tailed) & & .740 \\
\hline & $\mathrm{N}$ & 30 & 30 \\
\hline \multirow[t]{3}{*}{ Team formation } & $\begin{array}{l}\text { Pearson } \\
\text { Correlation }\end{array}$ & .378 & 1 \\
\hline & Sig. (2-tailed) & .740 & \\
\hline & $\mathrm{N}$ & 30 & 30 \\
\hline
\end{tabular}

From Table 4.1 shows that $r=0.378$ depicting a significant moderate positive relationship between team formation and performance of communitybased projects

Objective Two: Correlation of Team Motivation and Performance of Community-based Projects

Using Pearson's Correlation Method, the relationship between team motivation and performance of community-based projects was computed and the correlational results are presented in Table 4.2

Table 4.2. Correlation of Team Motivation and Performance of Community-based Projects

\begin{tabular}{llll}
\hline & & Performance & Team motivation \\
\hline $\begin{array}{l}\text { Performance of } \\
\text { community-based } \\
\text { projects }\end{array}$ & $\begin{array}{l}\text { Pearson } \\
\text { Correlation }\end{array}$ & 1 & .729 \\
& Sig. (2-tailed) & & .690 \\
Team motivation & N & 30 & 30 \\
& Pearson & .729 & 1 \\
& Correlation & & \\
& Sig. (2-tailed) & .690 & 30 \\
\hline & N & 30 & \\
\hline
\end{tabular}


Results from Table 4.2, that $\mathrm{r}=0.729$ depicting a significant moderate strong positive relationship between team motivation and performance of community-based projects.

Objective Three: Correlation of Team Communication and Performance of Community-based Projects

Using Pearson's Correlation, the relationship between team communication and performance of community-based projects was computed and the correlational results are presented in Table 4.3

Table 4.3. Correlation of Team Communication and Performance Community-based Projects

\begin{tabular}{|c|c|c|c|}
\hline & & Performance & Team communication \\
\hline \multirow{4}{*}{$\begin{array}{l}\text { Performance of } \\
\text { community-based } \\
\text { projects }\end{array}$} & Pearson & 1 & .623 \\
\hline & Correlation & & \\
\hline & Sig. (2-tailed) & & .754 \\
\hline & $\mathrm{N}$ & 30 & 30 \\
\hline \multirow[t]{3}{*}{$\begin{array}{l}\text { Team } \\
\text { communication }\end{array}$} & $\begin{array}{l}\text { Pearson } \\
\text { Correlation }\end{array}$ & .623 & 1 \\
\hline & Sig. (2-tailed) & .754 & \\
\hline & $\mathrm{N}$ & 30 & 30 \\
\hline
\end{tabular}

Table 4.3 shows that $r=0.623$ depicting a significant strong positive relationship between team communication and performance of communitybased projects.

Objective Four: Correlation of Team Dispute Resolution and Performance of Community-based Projects

Using Pearson's Correlation Method, the relationship between team dispute resolution and performance of community-based projects was computed and the correlational results are presented in Table 4.4

Table 4.4. Correlation between Team Dispute Resolution and Performance of Community-based Projects

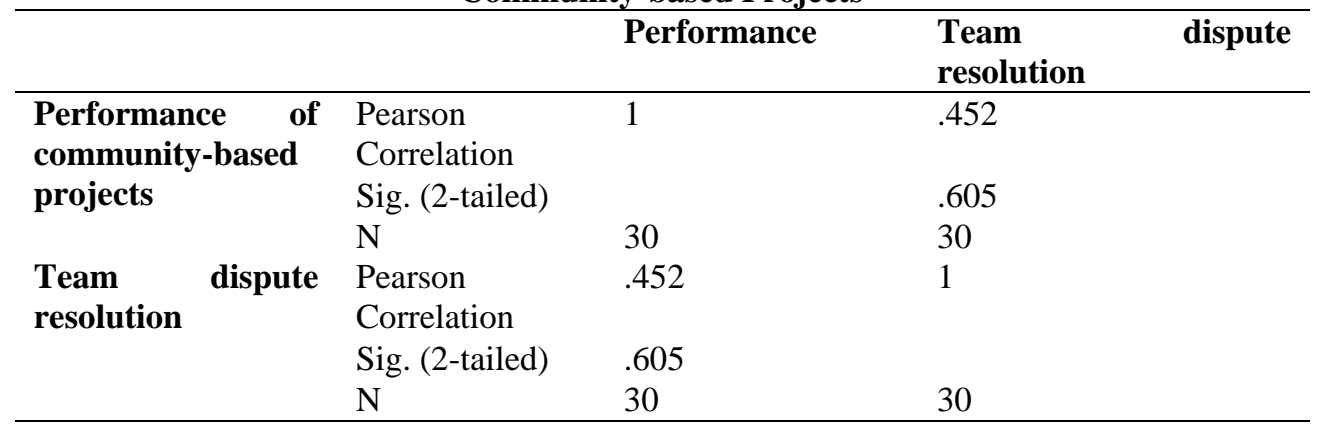

Table 4.4 shows that $r=0.452$ depicting a significant moderate positive relationship between team dispute resolution and performance of community-based projects. 


\section{Testing of Hypothesis}

The following hypothesis was tested:

$\mathbf{H}_{\mathbf{0}}$ : There is no significant influence of team management practices on the performance of community-based projects

$\mathbf{H}_{\mathrm{A}}$ : There is significant influence of team management practices on the performance of community-based projects

The regression model used to test the substantive hypothesis was as follows:

Performance of community-based projects and team management practices $=\mathrm{f}($ team management practices $)$

$\begin{array}{ll} & Y=\beta_{0}+\beta_{1} X_{1}+\beta_{2} X_{2}+\beta_{3} X_{3}+\beta_{4} X_{4}+\varepsilon, \text { Where; } \\ Y: & \text { Performance of community-based projects } \\ X_{1}: & \text { Team formation } \\ X_{2}: & \text { Team motivation } \\ X_{3}: & \text { Team communication } \\ X_{4}: & \text { Team dispute resolution } \\ \beta_{0}: & \text { Constant term } \\ \beta_{1}, \beta_{2}, \beta_{3}, \beta_{4} & \text { Beta coefficients } \\ \varepsilon & \text { Error term }\end{array}$

After data analysis, regression results for the influence of the team management practices on the performance of community-based projects is presented in Table 4.5.

Table 4.5. Multiple regression results for the combined team management practices on the performance of community-based projects

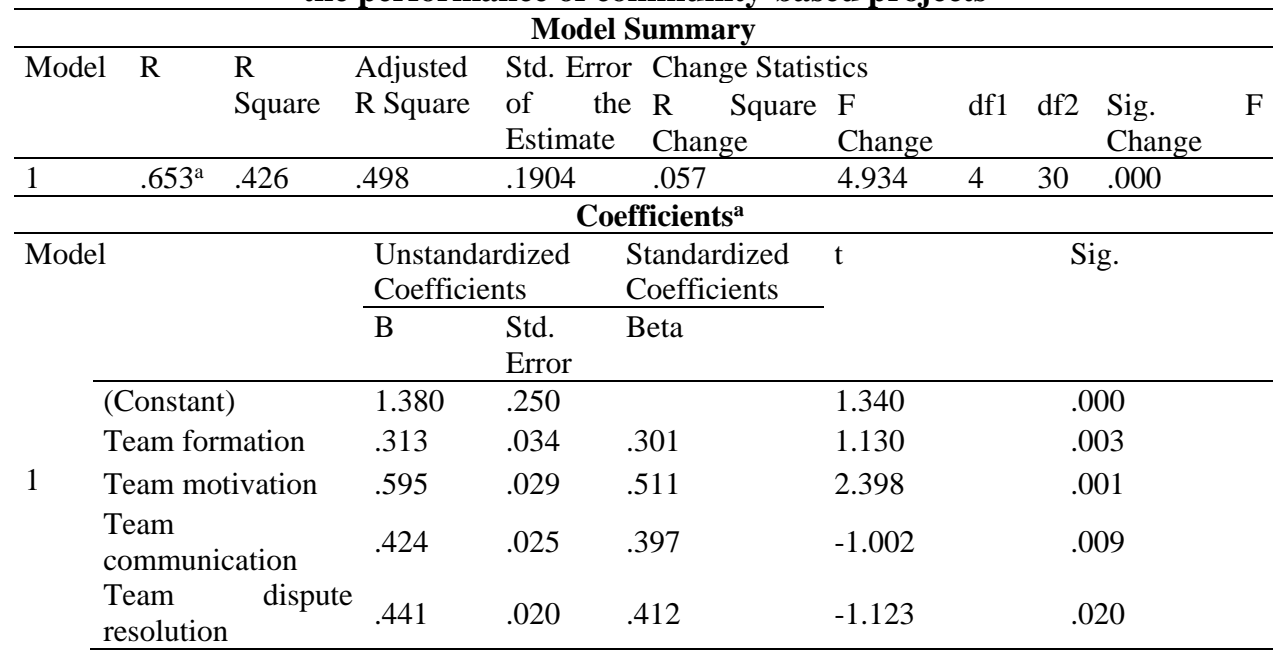

Predictors: (Constant), Team formation, Team motivation, Team communication, Team dispute resolution

Dependent Variable: Performance of community-based projects

$\mathrm{F}(1,156)=4.934$ at $\mathrm{p}=0.000<0.05, \mathrm{r}=0.563, \mathrm{R}-$ Squared $=0.426$ 
With $\mathrm{r}=0.653$, it implies that there exists a positive slope between the independent variables (team formation, team motivation, team communication, team dispute resolution) and the dependent variable (performance of community-based projects). Overall $\mathrm{F}$ statistics was ( $\mathrm{F}$ $(1,156)=4.934)$ which shows that there exists a positive correlation and the slope of the population regression line is not zero. Beta coefficients are as follows: team formation is $\beta_{1}=0.313$, team motivation $\beta_{2}=0.595$, team communication $\beta_{1}=0.424$, team dispute resolution $\beta_{4}=0.441$ and constant $\beta_{0}=1.38$. Since $p$-value of 0.000 is less than 0.05 , null hypothesis at the $=0.05$ level of significance is rejected as there was enough evidence to indicate that there is significant influence of the combined team management practices on the performance of community-based project.

\section{Predicting the Model}

Using the statistical findings, the regression model $Y=\beta_{0}+\beta_{1} X_{1}+\beta_{2} X_{2}+\beta_{3} X_{3}+\beta_{4} X_{4}+\varepsilon$, can then be substituted as follows; $\mathrm{Y}=1.380+0.313 \mathrm{X}_{1}+0.595 \mathrm{X}_{2}+0.424 \mathrm{X}_{3}+$ $0.441 \mathrm{X}_{4}+\varepsilon$

The beta values imply that for a one-unit increase in the team formation, the performance of performance of community-based projects increases by 0.313 . A one-unit increase in team motivation, the performance of community-based projects increases by 0.595 . One-unit increase in team communication, the performance of community-based projects increases by 0.424 . One-unit increase in team dispute resolution, the performance of community-based projects increases by 0.441 . This, therefore, confirms that combined team management practices have a significant influence on the performance of community-based projects.

\section{DISCUSSIONS}

\section{Team Formation and Performance of Community-based Projects}

From the findings, team formation practices such as consideration of competence, past experience, positive attitude, interpersonal skills and commitment contributes to the project performance. This is indicated by the majority of the respondents who affirmed that project under consideration were accomplishing their goals within schedules and satisfying their customers beyond expectations. The findings are supported by the results from an experimental study to establish and device a team formation model for selecting teams by Omar, Aljasim, Ahmad et al (2015) that team formation approaches have significant impact on team performance. In support, Rong and Shao (2012) and Zenger (2009) aver that multiple criteria for selecting team members can improve the individual and team performance essential for project success. Theoretically, team formation practices are said to enhance 
team productivity and performance (Jayarathn and Weerakkody, 2016). In his theory of team development, Tuckman (1965) emphasize on the importance of selecting able team members who can suitably adapt stormy environment by norming with ease in order to execute. Further, system theory of organization (Pollack, 2007) connects ability of organizations to flexibly respond and adapt to the dynamic environment based on the ability of the employees to management change. Hence, competent team is a precursor for effective change, management and performance of the projects.

\section{Team Motivation and Performance of Community-based Projects}

The results suggest that team motivation through acts like training, rewarding, autonomy, talent recognition and development and fair resource sharing boosts morale of the team members which in turn reinforces their desires and efforts to productively achieve organization goals. Intrinsic and extrinsic motivation of the team members can be used to support the argument that that motivated people become committed and devote their efforts in performing their tasks thus boosting their productivity and over all realization for the project goals. In support, Dobre (2013) conducted a study on employee motivation and his findings support that team motivation empowers individuals and reduces absenteeism while increasing satisfaction and desires to accomplish individual tasks hence increased organizational performance. Theories of motivation hold similar views that motivation tools like rewards, praises and recognition etc. boost intrinsic motivation essential for boosting individual and team morale in coordinating efforts for continuous learning, improvement and project performance (Schnetler, Steyn and Van Staden, 2015). Equally, Abraham Maslow theory of motivation support that motivated individuals become better at doing what they are expected to do (Simons, Irwin and Drinnien, 1987). Similarly, theory of team development empathizes on the need of having motivated individuals in order to adapt and ensure smooth transition from formation, storming, norming, performing and adjourning stages hence successful execution and delivery of the tasks (Tuckman, 1965). Also, system theory of organization emphasizes that since projects are social systems, managers must integrate the internal and external environment in creating suitable conditions for team productivity and performance and motivation aspect that managers can adopt to boost teem integration (Bredille, 2008).

\section{Team Communication and Performance of Community-based Projects}

Effective team communication e.g. frequent communication, timely communication, clear communication, numerous communication channels and interactive communication enhances clarity of issues and improves quality of decisions thus increased individual outputs and overall project performance. 
As indicated in the findings, most of the respondents either agreed or strongly agreed that projects were performing as per the expectations. This was attributed to the positive climate and effective team communication which strengthens teams' sense of identification and loyalty to a project which in turn contributes project performance and success (Smidts, Pruyn and van Riel, 2001). In addition, communication practices that are simple, open, honest, timely, rich in content and rationale of requirements and relevant to individuals and project tasks are easy to comprehend and build trust that is essential for successful decision making and team performance (Thamhain 2004). In his theory of team development, Tuckman (1965) pose that for effective shift of individuals from storming to norming and performing there is need for effective communications in order to clarify goals, roles, resources and steer the team towards successful delivery of their mandates. Equally, intrinsic motivation is reinforced via communication like recognition, acknowledgement etc. The findings are supported by the system theory of organization that communication is the most effective tools for integrating people with the environment.

\section{Team Dispute Resolution and Performance of Community-based Projects}

Effective team dispute resolution practices such as clarification of goals, clarification of roles and task, creating comfortable team climate, participatory decision making and consensus building were found to boost stable and enabling environment for team to perform and hence overall project performance. As presented in the findings, most of the respondents strongly agreed or agreed that their projects were progressing well as per the schedules and cost plans. This aspect of project performance was attributed to the cohesive and cordial relationships created by effective dispute resolution mechanisms. In support, Tuckman (1965) proposes managers and leaders to have a trustworthy and genuine environment when transitioning stormy team environment to a normed and highly performing team organization. Similarly, system theory of organization suggest that project environment is very dynamic owing to multiple stakeholders, needs and external factors. Specifically, internal factors e.g. scarce resources, conflicting roles and tasks, pressure etc. would ultimately result into conflicts between individuals and / or units thus calling for systematic and holistic approach to solving such organization sources of conflicts (Bredille, 2008). Hence effective team dispute resolution promotes good relations between individuals and groups essential for effective coordination of efforts and resources for successful completion of project goals. 


\section{CONCLUSION}

This study sought to examine the relationship between team management practices as indicated by team formation, team motivation, team communication and team dispute resolution and performance of communitybased projects. The findings revealed a positive relationship that showed community-based projects are teamwork driven. This implies that communitydevelopment projects need to employ team management strategies that enhance their abilities and capacities to perform better and improve the overall project performance. This is emphasized by Jayarathn and Weerakkody (2016) that effective development methodologies go along with boosting team productivity and organization performance. Due to the commune nature of community projects, it is recommended that community developers develop relevant and appropriate team management approaches that will not only hold the community together but also boost their commitment to perform better.

\section{RECOMMENDATIONS}

Practitioners of community project development should ensure structured and multi-criteria strategy towards effective management of project teams. The strategy should focus on selecting competent and able team members. In addition, there is need to develop and motivate the team members and creating favorable work environment essential for boosting team productivity. Equally, effective team communication should embrace to as to enforce understanding and right responses. Finally, there need to develop effective internal mechanisms for solving disagreements and disputes so as to avoid extreme eventualities like conflicts which may hamper project performance.

Based on the methodological limitations of this study, future researchers should consider triangulation of both qualitative and quantitative data so as to saturate evidence for concluding the results. Equally, future studies should focus on disaggregated projects across settings to as to promote generalization of the findings across diverse population settings. Specific studies should focus on influence of team dynamics and team characteristics on the performance of community projects.

\section{References:}

1. Ancona, D. \& Caldwell, D. (1992). Demography and design: Predictors of new product team performance. Organization Science, 3(3): 321-341.

2. Antoniadis, D. N., (2012). Complexity and the Process of Selecting Team Members: Journal for the Advancement of Performance Information and Value. Vol. 4 (1) 
3. Best, J. W., \& Kahn, J. (2009). Research in education, New Delhi \& Prentice Hall,India

4. Bredille, C. N. (2008). Exploring Research in Project Management: Nine Schools of Project Management Research (Part 4). Project Management Journal. Volume 39 (1).

5. Chan, A. P. C. \& Chan, A. P. L. (2004) Key Performance Indicators for measuring construction success. Benchmarking: An International Journal, 11(2), 203-221

6. Chiocchio, F. (2007). Project team performance: A study of electronic task and coordination communication. Project Management Journal, 38, 97-109

7. Claymome, Y. \& Jaiborisudhi, W. (2011). Sustainable local development through One Town One Product: An Overview of OTOP in Thailand, The International Journal of East Asian Studies. Vol 16 (1).

8. Dobre, O. (2013). Employee motivation and organizational performance. Review of Applied Socio- Economic Research. Vol. 5, Issue 1/ 2013)

9. Fincham, J. E. (2008). Response Rates and Responsiveness for Surveys, Standards, and the Journal. Am J Pharm Educ. 2008 Apr 15; 72(2): 43 .

10. Githua, R. W. \& Wanyoike, D.M. (2015). Factors influencing performance of community water projects in Njoro sub county; International Journal of Economics, Commerce and Management. Vol. III, Issue 11

11. Hofisi, C., \& Chizimba, M., (2013). The Sustainability of Donor Funded Projects in Malawi. Mediterranean Journal of Social Sciences Vol. 4 (6).

12. Hyvari, I, (2006). Success of projects in different organizational conditions; Project Management Institute, Vol. 37, No. 4, 31-41,

13. Jayarathna, D., Y., \& Weerakkody, W.A.S., (2016). Impact of Decision Making, Reward Management on Job Performance: Mediation of Job Satisfaction: A Case of a Private Banks in Sri Lanka. European Journal of Business and Management. Vol.8 (32)

14. Kara, N. K., \& Kester, Q., (2015). The Impact of Effective Team Management on Team Productivity: A Case Study of Ghana Broadcasting Corporation Education Project. International Journal of Social Sciences (2015).

15. Krejcie, R.V. \& Morgan, D. W. (1970). Determining Sample Size for Research Activities Educational and Psychological Measurement, Vol. 30(608), Sage Publishers. 
16. Lindsjorn, Y., Sjoberg, D. I.K., Dingsoyr, T., Bergersen, G. R. \& Dybaa, T., (2016). Teamwork quality and project success in software development: A survey of agile development teams; The Journal of Systems and Software, Vol 122 (2016).

17. McManus, J. \& Wood-Harper, T. (2007). Understanding the sources of Information System Project Failure. Journal of the Management Sciences Institute. Vol. 51 (2).

18. Mose, J. A. \& Kibera, F. N. (2015). The influence of service quality management practices on the performance of hotel firms in Kenya. European Scientific Journal August: Vol.11, No.22

19. Muller, R. \& Jugdev, K., (2012). Critical success factors in projects: Pinto, Slevin, and Prescott - the elucidation of project success", International Journal of Managing Projects in Business, Vol. 5 Iss: 4, pp. $757-775$

20. Mwaura, M., \& Ngugi, K. (2014). Factors affecting performance of community-based organizations projects in Kisii County Kenya. International Journal of Social Sciences Management and Entrepreneurship, 1 (2), 51- 67

21. OECD (2016). Geographical Distribution of Financial Flows to Developing Countries 2016: Disbursements, Commitments, Country Indicators, OECD Publishing, Paris.

22. Ohaya, O.O., Misigah, G., \& Kinyanjui, C. (2015). One Village One Product (OVOP)-Regional Sustainable Development in Kenya. International Journal of Science and Research. Vol. 4 (1).

23. Oino, P. G., Towett, G., Kirui, K. K, \& Luvega, C. (2015). The dilemma in sustainability of community-based projects in Kenya. Global Journal of advanced research. Vol-2 (4)

24. Parker, G. M. (2008). Team Players and Teamwork; New Strategies for Developing Successful Collaboration ( $2^{\text {nd }}$ Edtn), John Wiley \& Sons, Inc

25. Peredo, A. M. \& Chrisman, J. (2006). Toward a Theory of Community-Based Enterprise. Academy of Management Review, Vol.31 (2).

26. Peterson, T. M. (2007). Motivation: How to Increase Project Team Performance. Project Management Journal, 38(4), pp. 60-69.

27. Pinto, M. B. \& Pinto, J.K., (1990). Team communication \& cross functional co-operation in new program development. Journal of Production Innovation Management, Vol.7 (3)

28. Pollack, J., 2007. The changing paradigms of project management. International journal of project management 25 (3), 266-274. 
29. Project Management Institute. (PMI, 2013). A Guide to the Project Management Body of Knowledge (PMBOK Guide), Fourth Edition. Newtown Square, PA

30. Ramabadron, R., Dean, J.W. Jr. \& Evans, J. R. (1997). Benchmarking and project management: a review and organizational model. Benchmarking for Quality Management \& Technology, 4, 58.

31. Republic of Kenya (2017). Investment profile for Embu County, Ministry of Investment, Industrialization, Trade \& Tourism, Embu County.

32. Republic of Kenya (2018). Status report for youth development in Embu County. Printer

33. Rong, G. \& Shao, D., (2012). Delivering software process-specific project courses in tertiary education environment: challenges and solution. In Software Engineering Education and Training (CSEE\&T), 2012 IEEE 25th Conference on. IEEE, pp. 52-61

34. Sadeh, A, Dvir, D, \& Shenhar, A (2000) The role of contract type in the success of $\mathrm{R} \& \mathrm{D}$ defence projects under increasing uncertainty. Project Management Journal, 31(3)

35. Schnetler, R, Steyn, H. \& van Staden, P.G. (2015). Characteristics of matrix structures, \& effects on project success. S. African Journal of Industrial Engineering Vol 26(1)

36. Shenhar, J. A, Levy, O. \& Dvir, D. (1997). Mapping the dimensions of project success. Project Management Journal:The Professional Journal of the Project Management Institute Volume 28(2)

37. Simons, J. A, Irwin D. B. \& Drinnien E. A. (1987). From Psychology -The Search for Understanding, Maslow's hierarchy of needs. NewYork. West publishing company

38. Smidts, A., Pruyn, A. T. H., \& van Riel, C. B. M. (2001). The impact of employee communication and perceived external prestige on organizational identification. The Academy of Management Journal, $1-29$.

39. Srikaew, A. \& Baron, S. (2009). Marketing Strategies Supporting National Plans: Contributions of Universities. Journal of Strategic Marketing, Vol.17(2).

40. Teller, J., \& Kock, A. (2013). An empirical investigation on how portfolio risk management influences project portfolio success. International Journal of Project Management, 31(6)

41. Thamhain, H. (2004). Leading technology-based teams. Engineering Management Journal, 16 (2), 36-42.

42. Thomas, K. W, \& Schmidt, W H. (1976). A survey of managerial interests with respect to conflict. Academy of Management Journal, $315-318$. 
43. Torri, M. (2009). Community entrepreneurship among lower castes in India: A grassroots contribution toward poverty alleviation \& rural development under conditions of adversity \& environmental uncertainty. Journal of Developmental Entrepreneurship, Vol.14 (4)

44. Tsiga, Z., Emes, M. \& Smith, A. (2016). Critical success factors for the construction industry. Project Management World Journal. Vol. V, Issue VII

45. Tuckman, B. W. (1965). Developmental Sequence in Small Groups', Psychological Bulletin 63.

46. Wu, M.C. \& Chen, Y.H. (2014). A factor analysis on teamwork performance - an empirical study of inter-instituted collaboration. Eurasian Journal of Educational Research,55.

47. Zwikael, O, \& Ahn M. (2011). The effectiveness of risk management process: analysis of project risk planning across industries and countries. Risk Anal, Volume 31(1) 